A É

\title{
Research Article: Physiology of drought tolerance in selected Rabi sorghum [Sorghum bicolor (L.) Moench] genotypes
}

V.D. SALUNKE, A.G. MUNDHE, R.R. DHUTMAL AND S.N. WAGHMARE

Article Chronicle: Received :

05.07.2017;

Accepted :

22.07.2017

KeY Words:

Physiology, Drought

tolerance, Rabi,

Sorghum
SUMMARY : A field experiment entitled "Physiological studies in some selected Rabi germplasm of sorghum [Sorghum bicolor (L.) Moench]" was conducted to study the germplasm lines for morphophysiological traits for drought tolerance and to identify germplasm lines with drought adaptations traits at the Sorghum Research Station, Marathwada Agricultural University, Parbhani during Rabi season 2006-07. Genotype GP 1 recorded the highest AGR, (1.090 g/day/plant)and RGR (0.011 g/g/day) at in between 90 DAS-harvest stage. Further this genotype also recorded the highest LAI (2.13) and the highest LAD (51.30 day). Whereas, genotype IS 5589 recorded the highest NAR ( $\left.0.062 \mathrm{~g} / \mathrm{dm}^{2} / \mathrm{day}\right)$ at 90 DAS-harvest and genotype IS 6368 at 45-60 and -75 days after sowing stage. The genotype GP 1 was superior in terms of grain yield indicating that importance of soil moisture at early growth period i.e. at sowing and panicle emergence. High grain $\left(2837 \mathrm{~kg} / \mathrm{ha}^{-1}\right)$ and fodder yield $(71.01 \mathrm{q} / \mathrm{ha})$ was observed in GP 1 as compared with check M 35-1 (1620 kg/ha). The increase in harvest index was found more in GP $1(28.54 \%)$ because of effective translocation of dry matter from vegetative parts to economic parts.

How to cite this article : Salunke, V.D., Mundhe, A.G., Dhutmal, R.R. and Waghmare, S.N. (2017). Physiology of drought tolerance in selected Rabi sorghum [Sorghum bicolor (L.) Moench] genotypes. Agric. Update, 12(TECHSEAR-1) : 83-87; DOI: 10.15740/HAS/AU/12.TECHSEAR(1)2017/83-87.
Author for correspondence :

\section{A.G. MUNDHE}

Wheat and Maize

Research Unit

(V.N.M.K.V.), PARBHANI

(M.S.) INDIA

Email:anil.gm143@gamil.

com

See end of the article for authors' affiliations 